\title{
Orthopteran insects as potential and preferred preys of the Red-footed Falcon (Falco vespertinus) in Hungary
}

\author{
GERGELY SzÖVÉNYI
}

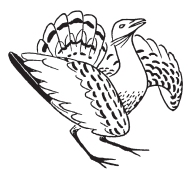

Gergely Szövényi 2015. Orthopteran insects as potential and preferred preys of the Redfooted Falcon (Falco vespertinus) in Hungary. - Ornis Hungarica 23(1): 48-57.

\section{ences of the taxa identied as prey. During the present}

Abstract Orthopterans play an important role in Red-footed Falcon diet, however, most studies focus only on its qualitative food composition, and less on quantitative composition and prefercarried out in the Red-footed Falcon study area, Vásárhelyi Plain (SE-Hungary) between 2006 and 2008. Grasshoppers were sampled in their main habitats by sweep netting and pitfall trapping, and orthopterans were identified in the food remnants collected from the nests, both artificial and natural ones. 26 species were detected during the field works, 18 species from the food remnants. Altogether 32 species were identified. Prey preference values for all species for each year were calculated. More than two thirds of the identified preys were Decticus verrucivorus, and nearly $20 \%$ were Tettigonia viridissima. Other common prey species were Melanogryllus desertus, Platycleis affinis, Gryllotalpa gryllotalpa, Calliptamus italicus and Gryllus campestris. Based on the prey preference analysis, the most preferred species was Decticus verrucivorus with extreme high values, and the other preferred ones, overlapping with the previous list, were Platycleis affinis, Bicolorana bicolor, Tettigonia viridissima, Calliptamus italicus and Roeseliana roeselii. These results may help in the development of Red-footed Falcon-friendly habitats through the application of habitat management favourable for the preferred prey species.

Keywords: Red-footed Falcon, Hungary, Orthoptera, prey composition, prey preference

Összefoglalás A kék vércse táplálkozásában az egyenesszárnyúak kiemelkedő fontosságúak, a táplálkozás-vizsgálattal foglalkozó kutatások azonban jobbára csak a táplálék összetételére vonatkoznak és fajlistákat közölnek, mennyiségi és preferencia-viszonyokat kevésbé tárnak fel. A munka során 2006-2008-ig a Vásárhelyi-pusztán kialakított Kékvércse-védelmi és Kutatási Mintaterületen végeztem a helyi kék vércse populáció táplálkozóhelyein kiterjedt orthopterológiai vizsgálatokat. A főbb jelen lévő egyenesszárnyú élőhelyeken fühálózással és talajcsapdázással végeztem mintavételeket, illetve a kék vércsék fészkeiből gyüjtött táplálékmaradványokból azonosítottam az egyenesszárnyúakat. A terepi mintavételek során 26, a táplálékmaradványokból 18, összesen 32 fajt sikerült kimutatni a területről. Az egyes zsákmány fajok preferenciáját az egyes évekre külön kiszámoltam. A zsákmányolt fajok közül a szemölcsevő szöcske (Decticus verrucivorus) több mint a zsákmány kétharmadát, a zöld lombszöcske pedig közel 20\%-át alkotta, a további gyakoribb prédái a Melanogryllus desertus, Platycleis affinis, Gryllotalpa gryllotalpa, Calliptamus italicus és a Gryllus campestris voltak. A preferencia elemzés alapján a legkedveltebb préda szintén a szemölcsevő szöcske volt extrém magas értékekkel, a többi pedig részben átfedöen az elözőekkel a Platycleis affinis, Bicolorana bicolor, Tettigonia viridissima, Calliptamus italicus és a Roeseliana roeselii volt. Az eredmények a preferált prédafajoknak kedvező élőhely-kezelések alkalmazása révén segíthetnek a kék vércse-barát élőhelyek kialakításában.

Kulcsszavak: kék vércse, Magyarország, egyenesszárnyú rovarok, zsákmány összetétel, zsákmány preferencia

Department of Systematic Zoology and Ecology, Eötvös Loránd University, 1117 Budapest, Pázmány Péter sétány 1/C, Hungary,e-mail: szovenyig@gmail.com 


\section{Introduction}

The Red-footed Falcon (Falco vespertinus) is a general avian predator (Cramp \& Simmons 1980) widely distributed in the Eurasian steppe zone. In its breeding season it prefers different types of open habitats including steppes, forest-steppes and extensively cultivated agricultural landscapes as well, where forest patches or small groups of trees provide it with suitable nesting places and grasslands or mosaic agricultural fields, which supply it with enough food (Palatitz et al. 2009, 2015). It preys mammals, reptiles, amphibians and different insects (Palatitz 2012) of a wide range of size down to 1-2 mm (Haraszthy et al. 1994). During the breeding season Red-footed Falcons feed on small rodents, anurans, spiders and different insects, especially on Orthoptera, Odonata and Coleoptera (Keve \& Szijj 1957) species. Most of data available on its diet are mainly based on prey remnants collected from nests, and these show that orthopteran insects form a considerable and stable part of the food for the young birds. An extensive study of Haraszthy et al. (1994) conducted in the Hortobágy region (East Hungary) found that orthopteran prey items form the largest part of the detectable prey biomass. The breeding population of the Red-footed Falcon shows a considerable decline during the past decades throughout most of its distribution range (Palatitz et al. 2009, 2015), thus the knowledge about its diet is crucial for the appropriate habitat management in its breeding and feeding habitats.

Although previous studies on the diet of the Red-footed Falcon provided detailed information on food composition, until now, a quantitative analysis about their real prey preference in ecological terms has not been published. Thus, the main aim of the present investigation was to obtain relevant information on the potential orthopteran prey availability of a Red-footed Falcon population in Hungary, and to determine their prey preferences in order to provide a basis for the falcon-friendly management of these habitats.

\section{Material and methods}

\section{Study area}

Field investigations were carried out in the Red-footed Falcon study site, Vásárhelyi Plain (SE Hungary), between 2006 and 2008 (Kotymán et al. 2015). This area named after a shallow alkali lake located here -, together with the surrounding grasslands is among the largest continuous steppic remnants of south eastern Hungary. A stable population of Red-footed Falcons breeds here, mainly in artificial nest-boxes (Palatitz et al. 2011, 2015, Kotymán et al. 2015). The above indicated, $10 \times 10 \mathrm{~km}$ long term study site was designated here in 2006, in a frame of a conservation project funded by the LIFE Nature Fund for studying the ecology and conservation of the Red-footed Falcon in Hungary. The main habitat types of the study area and their proportions were precisely identified for each study year, using remote sensing techniques (Palatitz 2012). The main habitat categories were: grasslands, cereals, alfalfa fields, intertilled crops (e.g. maize and sunflower), artificial surface (e.g. roads, farm buildings), reedbeds, water surface and woods. The applied remote sensing methodology did not allow the separation of fallow land from grasslands. Since grasshoppers inhabit mainly open terrestrial habitats in this 
region, artificial surfaces, reedbeds, water surface and woods were excluded from the orthopterological investigation. Additionally, after the first study year, intertilled crops (maize fields) were also neglected, because the sampling methods used for grasshoppers were partly inapplicable in this habitat type and extremely low density of orthopteran insects was detected during the first year of field works.

\section{Sampling methods}

Two methods of different sensitivity were applied for sampling the potential Orthoptera prey availability in the studied habitats, including the grasslands and fallow as real habitat types separately (separated by recorded history of each arable field), because the local Orthoptera assemblages of these two latter habitat types showed considerable differences. Grasslands were also divided into two categories in 2006 (hayfields and pastures), but in 2007-2008 only hayfields were sampled.

Pitfall traps were used for the effective collection of ground-level inhabiting species (mainly crickets), while species living in the vegetation (mostly bush crickets and grasshoppers) were collected by sweep netting completed by visual and acoustic searching for species that are difficult to detect or rare (Ingrisch \& Köhler 1996, Southwood \& Henderson 2000). Two sampling plots were selected for each studied habitat type in each year. Pitfall traps (a line transect of 9 traps of $10 \mathrm{~cm}$ diameter, half filled with ethylene-glycol on each plot) were exposed for one month between June and July. In sweep netting, the sampling effort was 300 sweeps (net diameter: $40 \mathrm{~cm}$ ) for each sampling plot once a year between the end of June and the end of July. Field samplings were carried out during the nesting period of Red-footed Falcons. The materials of pitfall traps were identified in laboratory, while most specimens collected by sweeping were identified on the field and released afterwards alive in the same habitat in order to minimise the invasiveness of data collecting methods applied in the protected study area.

The food composition of a bird of prey, such as the Red-footed Falcon can be studied by analysing the food remains left in the nests (Haraszthy et al. 1994). This method provides reliable data with restrictions, since it shows mainly the food composition of nestlings, but, on the other hand, the food quality consumed by them has a strong effect on their future life perspective, thus the prey items detectable by this way probably demonstrate well the real food preferences of the species. Moreover, Red-footed Falcons commonly eat numerous insects which are generally seriously damaged during the digestion and/or after it in the nest, and the small parts like wings or legs of a grasshopper often disappear form the nest. This makes the exact identification of insect prey items at species level hard or sometime impossible. Food remnants were collected from several nests after the nesting period (in July or August) in the study area in each year in order to get enough data for the prey preference analysis. Prey remnants in collected samples were classified into larger groups (mammals, birds, amphibians, reptiles and arthropods) and Orthoptera remnants were indentified in laboratory using the identification keys of Harz $(1969,1975)$ and a comparative collection with separated body parts of species occurring in the study area based on the collected Orthoptera samples and the already published data (Nagy \& Szövényi 1998, Szövényi \& Nagy 1999) on the region's 
grasshoppers. A minimal number of specimens for each taxa identified in each sample (prey remnants collected from one nest) were obtained on the basis of the combination of body parts belonging to the minimal number of specimens of a taxa (e.g. a pair of mandibles, a pair of hind, middle and fore legs, wing parts, pronotum, head).

\section{Data analysis}

\section{Prey availability}

After the determination of all materials investigated, a list of taxa with number of individuals belonging to each was obtained for each sampling plot, each year and both sampling methods separately. Since the Orthoptera prey items identified from the food remnants could be captured by the Red-footed Falcons from any part of the study area suitable for grasshoppers, average data on availability of each orthopteran species were calculated for the whole study area. Main steps of this calculation are listed below.

Step 1: The lists of two sampling plots per real habitat types were summarized (numbers of specimens were added up) for each year and each sampling method separately.

Step 2: The numbers of specimens for each taxa were summed for each main habitat type category, for each year and each sampling method separately, when more than one real habitat type were sampled in one main habitat type category (e.g. for grasslands and oldfields). These were converted to percentage dominance values for each dataset. When only one real habitat type was sampled in one main habitat type category, the results of step 1 were converted into percentage values for each dataset.

Step 3: The percentage dominance lists created in step 2 were averaged for the two sampling methods separately in each main habitat type category and each year.

Step 4: The averaged percentage dominance datasets of the main habitat type categories for each year were weighed by their proportion to the whole area in the study area for each year (detailed in Palatitz 2012) and then averaged for the whole study area separately for each year.

Finally one list was obtained for each year containing all taxa detected during the field works in a particular year with their average dominance considering both sampling methods and the actual relative percentage proportion of each main habitat type category sampled.

It was hypothesized that Orthoptera samples are representative for their habitat type, and that the two applied sampling methods considered in equal weight represent well the real composition of the local assemblages and therefore the availability of the potential orthopteran prey species for the Red-footed Falcon. Although it is a highly simplified approach, but it is the only way in which the results can be made comparable with the prey consumption data obtained.

\section{Prey consumption}

Since the exact origin of prey specimens identified from the food remnants was unknown, prey 'specimens' from all nest samples were pooled into one list and average percentage frequency values of detected taxa were calculated for the whole data pool. The investigation of Palatitz et al. (2011) on the foraging habitat selection of this Red-footed Falcon population confirmed that presumably most of preys were captured inside the designated study area. 


\section{Prey preference}

The lists of averaged dominances, which denote potential orthopteran prey species availability for the whole study area in each year and the lists of summarized percentage prey frequency for the whole Redfooted Falcon population breeding in the study area in each studied year make it easy to calculate ecological preference values of this population for each prey species and each year. It was calculated by a simple division (prey consumption frequency divided by the prey dominance). When the preference value was above 1 , the consumption of that prey species was larger than its averaged availability, which means that this species was preferred by the Red-footed Falcons in that year, while when the value was between 1 and zero, it means that these species were not actively chosen by the birds. In the special case when only one list contained a potential species, the preference value could not be calculated. If the particular species was not detected during the Orthoptera sampling, however it was found in the food remnants, it could be considered to be highly preferred, and in an opposing case it was avoided.

\section{Results}

\section{Potential orthopteran prey availability and food composition}

During the 3 year-long study, 5879 specimens of Orthoptera were sampled and identified in the field samplings in the Kardoskút study site (3504 by sweeping and 2375 by pitfall trapping) belonging to 26 species (Table 1). 26.7 percents of it were nymphs, identifiable only at genus level. The mini- mal number of Orthoptera specimens identified in Red-footed Falcon food remnants was 5164 during the whole investigation (2006: 544 specimens from 39 nests; 2007: 1450 specimens from 130 nests; 2008: 3170 specimens from 54 nests) belonging to 18 identifiable species (Table 1). Here only 2 percent of all specimens were identifiable only at higher levels (genus or family). Altogether 32 Orthoptera species were detected during the whole study (Table 1), 14 species were found only during the field samplings, but individuals of six species were preyed on only by the Red-footed Falcons.

\section{Prey preferences}

Prey preference values of all orthopteran species found in the food remnants were calculated for each year and these values were averaged as well (Table 2). Species which were preferred by Red-footed Falcons at least in one studied year according to the calculated preference values were indicated with bold letters in Table 2 .

\section{Discussion}

The extensive field sampling showed that the study area is rich in orthopterans; $25 \%$ of the species occurring in Hungary (Panrok \& Szövényi 2013) were found here. Some nationally protected species were among them (Gampsocleis glabra, Tettigonia caudata), a cricket (Modicogryllus truncatus), which since then also became protected, proved to be new for the Hungarian fauna (Szövényi 2011) and some of them (Stethophyma grossum, Platycleis albopunctata grisea) were not published before in the administrative area of the Körös-Maros National Park Directorate (Nagy \& Szövényi 


\begin{tabular}{|c|c|c|c|c|c|c|}
\hline & \multicolumn{3}{|c|}{ Field sampling } & \multicolumn{3}{|c|}{ Food remnants } \\
\hline & 2006 & 2007 & 2008 & 2006 & 2007 & 2008 \\
\hline \multicolumn{7}{|l|}{ Ensifera } \\
\hline Leptophyes albovittata & + & + & + & & & \\
\hline Conocephalus fuscus & & + & + & & & \\
\hline Conocephalus dorsalis & & & + & & & \\
\hline Ruspolia nitidula & & & & + & & \\
\hline Decticus verrucivorus & + & + & + & + & + & + \\
\hline Bicolorana bicolor & + & + & + & + & + & + \\
\hline Roeseliana roeselii & + & + & + & + & + & + \\
\hline Platycleis affinis & + & + & + & + & + & + \\
\hline Platycleis albopunctata grisea & & & & & + & \\
\hline Tessellana veyseli & + & + & + & + & + & + \\
\hline Gampsocleis glabra & + & & & & & \\
\hline Tettigonia caudata & & & & + & + & + \\
\hline Tettigonia viridissima & + & + & + & + & + & + \\
\hline Gryllus campestris & + & + & + & + & + & + \\
\hline Melanogryllus desertus & + & + & + & + & + & + \\
\hline Modicogryllus bordigalensis & + & & + & & & \\
\hline Modicogryllus truncatus & & & + & & & \\
\hline Oecanthus pellucens & & + & + & & & \\
\hline Gryllotalpa gryllotalpa & & & & + & + & + \\
\hline \multicolumn{7}{|l|}{ Caelifera } \\
\hline Tetrix subulata & + & & & & & \\
\hline Calliptamus italicus & + & + & + & + & + & + \\
\hline Pezotettix giornae & + & + & + & + & & \\
\hline Chorthippus brunneus & + & + & + & & & \\
\hline Chorthippus dichrous & & + & & & & \\
\hline Chorthippus oschei & + & + & + & + & + & \\
\hline Dociostaurus brevicollis & + & & & & & \\
\hline Euchorthippus declivus & + & + & + & & & \\
\hline Omocestus rufipes & + & + & + & & & \\
\hline Pseudochorthippus parallelus & + & + & + & & & \\
\hline Aiolopus thalassinus & + & + & + & + & + & + \\
\hline Oedaleus decorus & & & & + & & \\
\hline Stethophyma grossum & & & & & + & \\
\hline
\end{tabular}

Table 1. Orthoptera species identified during the field sampling (sweep netting and pitfall trapping) and in the food remnants of Red-footed Falcons in the Red-footed Falcon study site between 2006 and 2008

1. táblázat A terepi mintavételek során (fühálózás és talajcsapdázás) és a kék vércsék táplálékmaradványaiból azonosított Orthoptera fajok a Kékvércse-védelmi és Kutatási Mintaterületen 2006 és 2008 között 


\begin{tabular}{|c|c|c|c|c|c|}
\hline & $\begin{array}{c}\text { Total } \% \\
\text { proportion }\end{array}$ & $\begin{array}{l}2006 \\
\text { pref. }\end{array}$ & $\begin{array}{l}2007 \\
\text { pref. }\end{array}$ & $\begin{array}{l}2008 \\
\text { pref. }\end{array}$ & $\begin{array}{c}\text { Average } \\
\text { pref. }\end{array}$ \\
\hline \multicolumn{6}{|l|}{ Ensifera } \\
\hline Ruspolia nitidula & 0.02 & OR & & & \\
\hline Decticus verrucivorus & 64.18 & 719.87 & 369.87 & 251.21 & 446.98 \\
\hline Bicolorana bicolor & 0.21 & 7.58 & 5.78 & 1.13 & 4.83 \\
\hline Roeseliana roeselii & 0.37 & 0.83 & 0.26 & 1.13 & 0.74 \\
\hline Platycleis affinis & 3.66 & 19.24 & 26.55 & 9.35 & 18.38 \\
\hline Platycleis albopunctata grisea & 0.02 & & OR & & OR \\
\hline Tessellana veyseli & 0.41 & 0.09 & 0.1 & 0.2 & 0.13 \\
\hline Tettigonia caudata & 0.08 & OR & OR & OR & OR \\
\hline Tettigonia viridissima & 19.69 & 7.45 & 1.27 & 2.23 & 3.65 \\
\hline Gryllus campestris & 1.3 & 0.46 & 0.23 & 0.17 & 0.29 \\
\hline Melanogryllus desertus & 5.23 & 0.6 & 0.48 & 0.08 & 0.39 \\
\hline Gryllotalpa gryllotalpa & 2.46 & OR & OR & OR & OR \\
\hline \multicolumn{6}{|l|}{ Caelifera } \\
\hline Calliptamus italicus & 2.4 & 4.22 & 0.51 & 1.02 & 1.92 \\
\hline Pezotettix giornae & 0.02 & 0.11 & OS & OS & 0.04 \\
\hline Chorthippus oschei & 0.41 & 0.22 & 0.08 & OS & 0.10 \\
\hline Aiolopus thalassinus & 0.52 & 0.42 & 0.47 & 0.73 & 0.54 \\
\hline Oedaleus decorus & 0.02 & OR & & & OR \\
\hline Stethophyma grossum & 0.02 & & OR & & OR \\
\hline
\end{tabular}

Table 2. Prey preference values for Orthoptera species identified from the food remnants of Redfooted Falcons in the study site between 2006 and 2008 (Total \% - percentage proportion in the total pool of food remnants collected during the whole study period including specimens not identifiable at species level; OR - species found only in food remnants; OS - species found only by Orthoptera sampling)

2. táblázat A kék vércse táplálékmaradványaiból azonosított Orthoptera fajok préda preferencia értékei a Kékvércse-védelmi és Kutatási Mintaterületen 2006 és 2008 között (Total \% - százalékos arány a vizsgálat teljes ideje alatt gyűjtött táplálékmaradványokban a faji szinten nem azonosítható példányokat is beleértve; OR - csak táplálékmaradványból előkerült faj; OS csak az egyenesszárnyú mintavételek során előkerült faj). A vastaggal szedettek a preferencia szerint 1 fölötti értékkel szereplő fajok, azaz az aktívan választott, keresett zsákmányok

1998, 1999, Szövényi \& Nagy 1999). At the same time, the fact that six species were detected only in the food remnants, locally rare species among them, well indicates that the sampling efforts were far not enough even, for the complete faunistical exploration of the study area. Beside the high abundance, the relatively high diversity of po- 
tential Orthoptera preys occurring in the feeding habitats of the studied Red-footed Falcon population, similarly to the Lesser Kestrel (Falco neumanni) (Rodrigez et al. 2010), also may indicate the good quality of this habitat complex for them. The results of Palatitz et al. (2011) on the foraging habitat selection of this population (preferences to grasslands and fallow land, neutrality to alfalfa and cereal fields and avoidance of intertilled crops, water surface, woods and artificial surfaces) confirm the representativity of the sampling method used from the point of view of sampled habitat types.

The prey composition of the studied Red-footed Falcon population (for a summary of all prey taxa found here in 2006 and 2007 see Böde 2008) was similar to the previous studies on the diet of this species (e.g. Keve \& Szijj 1957, Horváth 1964, Bezzel \& Hölzinger 1969, Fülöp \& Szlivka 1988, Haraszthy et al. 1994, Purger 1998, Molnár 2000). However, according to Purger (1998), the larger prey items are generally overrepresented in the food remnants collected from nests, because the larger parts are preserved better than the smaller, and therefore the more fragile pieces disappear. This opinion may have a real basis, but is controversial with the results of Haraszthy et al. (1994), who found small sized preys (between 5 and $10 \mathrm{~mm}$ ) to have the largest proportion in food remnant samples collected from nests.

Some widely distributed Orthoptera genera of large bodied species, like Tettigonia, Decticus, Platycleis, Gryllus, Gryllotalpa or Calliptamus (especially the females is this latter genus) seem to play an important role in the nutrition not only of the Red-footed Falcon in Central and Southeast Europe, but also of the similar Lesser Kestrel in Spain (Rodrigez et al. 2006). Considering only the composition of the food remnants, similarly to other studies, the most important prey species was the Wartbiter (Decticus verrucivorus), composing nearly $2 / 3$ of all prey specimens in the study area, while the Great Green Bush Cricket (Tettigonia viridissima) was the second most numerous species with a nearly $20 \%$ proportion altogether. The other species of larger proportion (more than 1\%: Melanogryllus desertus, Platycleis affinis, Gryllotalpa gryllotalpa, Calliptamus italicus, Gryllus campestris) were much less dominant. The preference values obtained have shown partly different patterns in term of the importance of preyed orthopteran species. These results confirm the importance of Wartbiter in the nutrition of species, even considering the opinion of Purger (1998) on the biases of the applied food remnant sampling method, since the preference values of this species were extremely high, between 720 and 251 during three consecutive study years, while the next category on the preference values was a mere 26 in case of the Platycleis affinis. Species preferred at least in one year largely overlapped with species of great proportion in the food (Decticus verrucivorus, Platycleis affinis, Bicolorana bicolor, Tettigonia viridissima, Calliptamus italicus and Roeseliana roeselii in order of the average preference values). According to the food remnants, the nymphs and adults of the large bodied, underground living European Mole Cricket (Gryllotalpa gryllotalpa) was the fifth most frequently captured orthopteran prey in the study area, and at the same time it was not detected even by the pitfall trapping, a method otherwise appropriate for its collection, and thus this species have also to be considered as a preferred prey. It shows that the Red-footed Falcons' hunting technique is quite effective, even in the case 
of a mostly underground insect. Another interesting phenomenon, which underlines the importance of the preference analyses, is the case of Melanogryllus desertus. This cricket species was the third most frequent species among the prey items, however, it was not actively chosen by the birds according to the preference analysis (average value: 0.39), highlighting the importance of such an analysis compared to the use of merely food composition for the evaluation of the importance of different prey species.

The results of the present study may help to form the preferred habitat types into a better source of foods for the Red-footed Falcons during their breeding period by optimizing the availability of the preferred prey

\section{References}

Bezzel, E. \& Hölzinger, J. 1969. Untersuchungen zur Nahrung des Rotfussfalken (Falco vespertinus) bei Ulm [Studies on the food of the Red-footed Falcon (Falco vespertinus) in Ulm]. - Anzeiger der Ornithologische Gesellschaft in Bayern 8: 446-451. (in German with English Summary)

Böde, Á. 2008. A kék vércse (Falco vespertinus) táplálkozásbiológiája [Nutrition biology of the Red-footed Falcon (Falco vespertinus)]. - MSc thesis, West Hungarian University, Sopron, pp. 38 (in Hungarian)

Cramp, S. \& Simmons, K. E. L. 1980. The birds of the western Palearctic, Vol. 2. - Oxford University Press, Oxford, pp. 695

Fülöp, Z. \& Szlivka, L. 1988. Contribution to the food biology of the Red-footed Falcon (Falco vespertinus). - Aquila 95: 174-181.

Haraszthy, L., Rékási, J. \& Bagyura, J. 1994. Food of the Red-footed Falcon in the breeding period. Aquila 101: 93-110.

Harz, K. 1969. The Orthoptera of Europe. I. Series Entomologica 5. - Dr. W. Junk Publishers, The Hague, pp. 750

Harz, K. 1975. The Orthoptera of Europe. II. Series Entomologica 11. - Dr. W. Junk Publishers, The Hague, pp. 939

Horváth, L. 1964. A kék vércse (Falco vespertinus L.) és a kis örgébics (Lanius minor Gm.) élettörténetének összehasonlító vizsgálata II. A fiókák kikelésétől az őszi elvonulásig [Comparative species through the perfect timing of different interventions (mowing, grazing etc.) in the habitats of these species.

\section{Acknowledgements}

The author thanks Péter Fehérvári, Péter Palatitz and Szabolcs Solt for their help in organising the field works, Zoltán Soltész for the operation of the pitfall traps, Ágnes Böde for the collection of food remnants and for its selection into larger groups. The study was financed by the LIFE Nature Fund of the European Union (LIFE05 $\mathrm{NAT} / \mathrm{H} / 000122$ ).

study on the life history of the Red-footed Falcon (Falco vespertinus L.) and the Lesser Grey Shrike (Lanius minor Gm.) II. From the hatching of chicks in the autumn migration]. - Vertebrata Hungarica 6: 13-39. (in Hungarian with German Summary)

Ingrisch, S. \& Köhler, G. 1996. Die Heuschrecken Mitteleuropas [The grasshoppers of Central Europe]. - Die Neue Brehm-Bücherei 629, Westarp Wissenschaften, Magdeburg, pp. 450 (in German) Keve, A. \& Szijj, J. 1957. Distribution, biologie et alimentation du Facon kobez Falco vespertinus L. en Hongrie [Distribution, biology and food of the Red-footed Falcon Falco vespertinus L. in Hungary]. - Alauda 25: 1-23. (in French)

Kotymán, L., Solt, Sz., Horváth, É., Palatitz, P. \& Fehérvári, P. 2015. Demography, breeding success and effects of nest type in artificial colonies of Red-footed Falcons and allies. - Ornis Hungarica 23(1): 1-21. DOI: 10.1515/orhu-2015-0001

Molnár, Gy. 2000. A kék vércse, a vörös vércse és az erdei fülesbagoly mesterséges telepítésének eredményei a Dél-Alföldön [The breeding of the Red-footed Falcon (Falco vespertinus), Kestrel (Falco tinnunculus) and Long-eared Owl (Asio otus) in artificial nest boxes in the Dél-Alföld region]. - Ornis Hungarica 10: 93-98. (in Hungarian with English Summary)

Nagy, B. \& Szövényi, G. 1998. Orthoptera együttesek a Körös-Maros Nemzeti Park területén [Orthoptera 
assemblages in the Körös-Maros National Park]. - Crisicum 1: 126-143. (in Hungarian with English Summary)

Nagy, B. \& Szövényi, G. 1999. A Körös-Maros Nemzeti Park állatföldrajzilag jellegzetesebb Orthoptera fajai és konzerváció-ökológiai viszonyaik [Zoogeographically characteristic orthopteroid insects of the Körös-Maros National Park and their nature conservation characteristics]. - Természetvédelmi Közlemények 8: 137-160. (in Hungarian with English Summary)

Palatitz, P. 2012. A kék vércse (Falco vespertinus) védelmének tudományos megalapozása [Scientific basement of the protection of the Red-footed Falcon (Falco vespertinus)]. - PhD thesis, Szent István University, Gödöllő, pp. 128 (in Hungarian with English Summary)

Palatitz, P., Fehérvári, P., Solt, Sz. \& Barov, B. 2009. European Species Action Plan for the Red-footed Falcon Falco vespertinus Linnaeus, 1766. - European Commission, pp. 49

Palatitz, P., Fehérvári, P., Solt, Sz., Kotymán, L., Neidert, D. \& Harnos, A. 2011. Exploratory analyses of foraging habitat selection of the Red-footed Falcon (Falco vespertinus). - Acta Zoologica Academiae Scientiarum Hungaricae 57: 255-268.

Palatitz, P., Fehérvári, P., Solt, Sz. \& Horváth, É. 2015. Hunting efficiency of Red-footed Falcons in different habitats. - Ornis Hungarica 23(1): 32-47. DOI: 10.1515/orhu-2015-0003
Panrok, A. \& Szövényi, G. 2013. First record and current distribution of Omocestus minutus (Brullé, 1832) (Orthoptera: Acrididae) in Hungary. - Articulata 28: 91-102.

Purger, J. J. 1998. Diet of Red-footed Falcon Falco vespertinus nestlings from hatching to fledging. Ornis Fennica 75: 185-191.

Rodriguez, C., Johst, K. \& Bustamante, J. 2006. How do crop types influence breeding success in Lesser Kestrels through prey quality and availability? A modelling approach. - Journal of Applied Ecology 43: 587-597.

Rodríguez, C., Tapia, L., Kieny, F. \& Bustamante, J. 2010. Temporal changes in Lesser Kestrel (Falco naumanni) diet during the breeding season in Southern Spain. - Journal of Raptor Research 44: 120-128. DOI: $10.3356 /$ JRR-09-34.1

Southwood, T. R. E. \& Henderson, P. A. 2000. Ecological methods. - Blackwell Science Ltd, Oxford, pp. 575

Szövényi, G. \& Nagy, B. 1999. Szikes és löszpuszta élőhelyek Orthoptera együtteseinek összehasonlító elemzése a Körös-Maros Nemzeti Park területén [Comparative analysis of the Orthoptera assemblages of alkali and loess grassland habitats in the Körös-Maros National Park]. - Crisicum 2: 115-122. (in Hungarian with English Summary)

Szövényi, G. 2011. First record of Modicogryllus truncatus in Hungary (Orthoptera: Gryllidae). - Folia Entomologica Hungarica 72: 9-12.

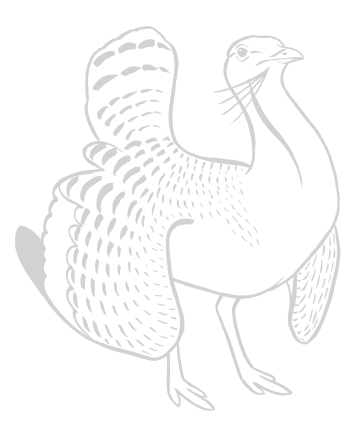

